students of the United States Pharmacopoeia and National Formulary to give a better understanding of these works. It is gratifying to add to one's pharmaceutical library one pharmaceutical text which is confined to comments of a pharmaceutical nature without going into details as regards chemistry, physics, pharmacology, etc. This is not intended as a criticism of the larger works on pharmacy which take up pharmaceutical chemistry and other branches besides pharmacy, for there is also need for such volumes for reference and study purposes. For the student who receives laboratory instruction in pharmacy as well as lectures on the art of pharmacy, this book is invaluable. It is also of great assistance to the practical druggist who desires to know the "whys and wherefores" of the directions which he follows in making pharmacopoeial and National Formulary preparations. The same high standard to which Professor Ruddiman's other publications conform is maintained in this volume and we predict for it a wide use and great popularity. ROBERT P. FISCHELIS.

Handbook of Pharmacognosy. By Otto A. Wall, M.D., Ph.D., Member of the Committee for Revision of the Pharmacopoeia of the United States, 1880-1890 and 1890-1900; Second Vice-President of the Convention for the Revision of the United States Pharmacopoeia from 1900-1910; Presiding Officer of the United States Pharmacopoeia Convention of 1910; Fourth Edition, Revised and Enlarged. St. Louis, C. V. Mosby Company, 1917. 629 pages.

The book is not divided into chapters.

The introduction of 27 pages discusses studies that should be fundamental or preliminary to the study of pharmacognosy and describes the various methods of classifying drugs to study them to the best advantage.

The classification adopted by the author is the one of Schimper and of Maisch, based on the physical characters of the drugs. His classification differentiates drugs into eightysix distinct classes or groups. The animal drugs are placed into the first eight groups; plants or flowering tops, sufficiently complete for botanical determination, constitute the ninth group; Algae, Lichens, Fungi, Lycopodiaceae, Equisetaceae and Ferns the next six groups and then follow roots, rhizomes, tubers, bulbs, twigs, woods, barks, leaves, flowers, fruits, seeds, etc., etc. The full classification of fruits is appended as a type of the entire classification.

Group 58. Spurious fruits, fresh (rose hips, apple).

59. Fleshy fruits, fresh (lemon, orange, apple, persimmon, raspberry, juniper berries).

6o. Stone fruits, fresh (raspberry).

61. Dried or prepared spurious fruits (hops, juniper berries, figs, long pepper, Am. wormseed).

62. Dry fruits (cardamom, star anise, poppy heads, St. John's bread, prickly ash berries, vanilla, cassia fistula, the Umbelliferous fruits, burdock seed, hemp seed, barley (malt).

63. Dried or prepared fleshy fruits (black pepper, capsicum, colocynth apple, raisins, poke berries, orange berries, clove fruits).

64. Dried or prepared stone fruits (cubeb, prune, saw palmetto, fish berries, buckthorn berries, allspice, sumach berries, cashew nut).

65. Parts of fruits (tamarind, white pepper, bitter and sweet orange peel, pomegranate rind, bael fruit, mangosteen, lemon peel).

A short section is devoted to the Method of Study used by the author. Each drug is to be treated according to the following outline: Name, Origin, Habitat, Description, Constituents, Uses, Dose.

Preceding the description of the vegetable drugs a section is devoted to Botany, Microscopy and Vegetable Histology.

The descriptions of the drugs are concise yet accurate and complete and the field of drugs is thoroughly covered, about 40 animal drugs and over 400 vegetable drugs being described. The illustrations while not "fancy" are accurate and instructive and especially interesting because they are original by the author. The typographical make-up of the book is very good.

The classification of drugs according to their physical characters is difficult under the best of circumstances but when a knowledge of botany is considered non-essential to the study of pharmacognosy such a classification must 
become very difficult indeed. Quotations from the author's section on Botany follow: "Botany is of comparatively subordinate interest to the pharmacist...." "If a student likes the study (of botany) and wishes to perfect himself in it, he should do so under no mistaken idea that it is essential to his becoming either a good pharmacist or a good pharmacognosist..." "Recognizing the minor value of a botanical classification of drugs, no stress is placed on this subject be- cause it is of little or no practical use to the pharmacognosist or pharmacist."

Another feature that seems "passing strange" is that no reference whatever was found in the book to the U. S. Pharmacopoeia or National Formulary except for a short paragraph in the preface. Personally, the reviewer has seen no text-book that is the equal of the botanical portions of these two national standards as a text for the study of pharmacognosy.

E. N. GatherRCoal.

\section{CHANGES OF ADDRESS.}

All changes of address of members should be sent to the General Secretary promptly.

The Association will not be responsible for non-delivery of the Annual Volume or Year Book, or of the Journal unless notice of the change of address is received before shipment or mailing.

Both the old and the new address should be given thus:

HENRY MirTON,

From 2342 Albion Place, St. Louis, Mo.

To 278 Dartmouth St., Boston, Mass.

Titles or degrees to be used in publications or in the official records should be given, and names should be plainly written, or typewritten.

CHANGES OF ADDRESS SNCE SEPT. 18, 1917.

BECKER, H. G.

From Pekin, I11.

To 2625 Ann Ave., St. Louis, Mo.

GaHn, HenRY.

From U. S. Marine Hosp., New Orleans, La.

To Pensacola Quarantine, Pensacola, Fla.

Colinins, Geo. W.

From 5 I43 Maple St., St. Louis, Mo.

To Box 66, Mt. Vernon, Ill.

Conlentz, V.

From 23 Vine St., Brooklyn, N. Y.

To Chemists' Club, 52 E. 4Ist St., New York, N. Y.

WiTT, C. T. A.

From 2 I $_{5}$ W. Ohio St., Chicago, Ill.

To 2212 Sedgewick St., Chicago, Ill.

DARCY, J. B.

From St. Vincent's Hosp., New York, N. Y.

To Residence Unknown.

DAWE, WM. H.

From 425 N. Wyoming St., Butte, Mont.

To Residence Unknown.

PARMELEE, H. L.

From Walsingham Apts., Cor. I6th \& Delaware, Indianapolis, Ind.

To 527 Lockerbie St., Indianapolis, Ind.

Rabinowitz, WM. J.

From 518 W. I34th St., New York, N. Y.

To care A. Daily, Rosenberg, Texas.

Chatfield, H. B.

From Residence Unknown

To Reed St., Lexington, Mass.
Gasen, Harry.

From Residence Unknown.

To Hospital Corps, U. S. A., Ft. Sheridan, Ill.

PeAT, C. A.

From Residence Unknown.

To zo Woodlawn Ave., Norwalk, Ohio.

LAMaR, W. R.

From 327 N. 18th St., East Orange, N. J.

To 8502 Ferriss St., Woodhaven, New York, N. Y.

SмIтн, WM. E.

From care Missoula Drug Co., Missoula, Mont.

To Residence Unknown.

LESLIE, F. A.

From 905 Jackson Ave., New York, N. Y.

To 79 Post Ave., New York, N. Y.

PATTERSON, JAMES N.

From 486 Geary St., San Francisco, Cal.

To I 40 Lincoln St., Santa Cruz, Cal.

SchuLz, H. L.

From I626 Transportation Bldg., Chicago, III.

To 64I Washington St., U. S. Food \& Drug Laboratory, New York, N. Y. DECEASED SINCE SEPT. $18,1917$.

Caspari, Chas., Jr.

Baltimore, Md.

Fox, P. P.

Philadelphia, Pa.

HAssinger, S. E. R.

Philadelphia, $\mathrm{Pa}$. 